\title{
LC-ESI-MS/MS Phenolic Profile of Volutaria lippii (L.) Cass. Extracts and Evaluation of Their In Vitro Antioxidant, Antiacetylcholinesterase, Antidiabetic, and Antibacterial Activities
}

\author{
Hichem Ben Salah $\mathbb{D}^{1},{ }^{1}$ Slim Smaoui, ${ }^{2}$ Raed Abdennabi, ${ }^{3}$ and Noureddine Allouche $\mathbb{D}^{1}$ \\ ${ }^{1}$ Laboratory of Organic Chemistry LR17ES08 (Natural Substances Team), University of Sfax, Faculty of Sciences of Sfax, Sfax, Tunisia \\ ${ }^{2}$ Laboratory of Microorganisms and Biomolecules of the Center of Biotechnology of Sfax, Road of Sidi Mansour Km 6, \\ Sfax 3018, Tunisia \\ ${ }^{3}$ Laboratory of Plant Biotechnology Applied to Crop Improvement, Faculty of Science, Sfax University, Sfax, Tunisia
}

Correspondence should be addressed to Hichem Ben Salah; hichembensalah9@gmail.com

Received 20 March 2019; Revised 21 May 2019; Accepted 2 June 2019; Published 24 June 2019

Academic Editor: Víctor López

Copyright (C) 2019 Hichem Ben Salah et al. This is an open access article distributed under the Creative Commons Attribution License, which permits unrestricted use, distribution, and reproduction in any medium, provided the original work is properly cited.

\begin{abstract}
Volutaria lippii (L.) Cass., an indigenous perennial herb from the Tunisian flora, belongs to the medicinally important genus Volutaria Cass. (Asteraceae) which comprises eighteen species widely distributed in the Irano-Turanian and Mediterranean Basin. In this study, five different extracts from Tunisian Volutaria lippii (L.) Cass. were evaluated for their in vitro antioxidant, antiacetylcholinesterase, antidiabetic, and antibacterial activities as well as for their total phenolic and flavonoid contents. The results indicated that the ethyl acetate and aqueous fractions have the highest levels in phenolic and flavonoid contents and showed remarkable antioxidant activities using DPPH $\left(\mathrm{IC}_{50}=11.50 \pm 0.57\right.$ and $28.81 \pm 1.35 \mu \mathrm{g} / \mathrm{mL}$, respectively), total antioxidant capacity $\left(105.21 \pm 0.01\right.$ and $98.77 \pm 0.02 \mathrm{mg}$ vitamin $\mathrm{E} / \mathrm{g}$ extract, respectively), and reducing power $\left(\mathrm{EC}_{50}=55.40 \pm 2.00 \mathrm{and} 66.65 \pm 1.40 \mu \mathrm{g} / \mathrm{mL}\right.$, respectively) methods. Furthermore, they exhibited noticeable antiacetylcholinesterase and antidiabetic activities and a moderate antibacterial effect when compared to that of standards. Principal component analysis allowed highlighting the ethyl acetate extract for its interesting acetylcholinesterase enzyme (AChE) and alpha-amylase activities and the aqueous fraction for its remarkably antibacterial activity, and their richness in phytochemical content. Interestingly, the LC-ESI-MS/MS analyses of both fractions allowed the identification of ten phenolic acids and eight flavonoids. The 3-O-caffeoylquinic and 3,4-di-O-caffeoylquinic acids constituted the most abundant components in the two fractions. Taken together, these findings demonstrated, for the first time, that Volutaria lippii (L.) Cass. is a potential source of biological active compounds which could be used in a wide range of fields, namely, nutrition and complementary pharmacological drug.
\end{abstract}

\section{Introduction}

The Tunisian flora has a wide plant varieties used not only in folk medicine, but also in pharmaceutical, cosmetic, and food technologies [1]. These plants represent an excellent reservoir for extracting and identifying bioactive phytochemicals, which exerted a beneficial effect on human healthiness [2] and had a preventive role against cancer and chronic diseases. Many of these natural compounds, such as polyphenols, flavonoids, and phenolic acids, are known for their various pharmacological activities including antioxidant, antimicrobial, antidiabetic, anti-inflammatory, anticancer, and antiAlzheimer effects $[3,4]$.

Volutaria lippii (L.) Cass. ex Maire (syn Centaurea lippii L., Volutarella lippii (L.) Cass., Amberboa lippii (L.) DC.) is one of the Tunisian plants that belong to the genus Volutaria Cass., tribe Cardueae, subtribe Centaureinae of the Asteraceae (Compositae) [5]. The genus Volutaria comprises approximately eighteen species growing in semiarid to arid zones and widely distributed in the Irano-Turanian 
and Mediterranean areas [6]. Pharmacological and phytochemical studies on several Volutaria species have reported that these plants are rich in sesquiterpene lactones and flavonoids which possess various biological activities [7, 8]. Previous study reported the isolation of one sesquiterpene lactone identified as cnicin and three flavonoids, identified as nicotiflorin, isovitexin and isoquercitrin, from the n-butanol extract of $V$. lippii [9]. Other works released on $V$. lippii were conducted to the isolation of two sesquiterpene lactones identified as amberboin and grosshemin $[10,11]$.

The aim of actual study was to evaluate the phytochemical screening (flavonoid and total phenolic contents) and in vitro antioxidant, antiacetylcholinesterase, antidiabetic, and antibacterial potentials of $V$. lippii. Moreover, the LC-ESIMS/MS technic was employed for qualitative and quantitative analyses of phytochemicals in ethyl acetate and aqueous fractions. This study was the first report depicting chemical profile and biological property evaluations of $V$. lippii extracts.

\section{Material and Methods}

2.1. Plant Material. Aerial flowering parts of $V$. lippii were collected in April 2014 from Sfax in the central east of Tunisia $\left(34^{\circ} 44^{\prime} 26.02^{\prime \prime} \mathrm{N}, 10^{\circ} 45^{\prime} 37.01^{\prime \prime} \mathrm{E}\right)$. A voucher specimen (Number LCSN 118) was deposited in the Herbarium Laboratory of Organic Chemistry (Natural Substances Team), Faculty of Sciences, Sfax University, Tunisia.

2.2. Chemicals and Reagents. 2,2-Diphenyl-1-picrylhydrazyl $(\mathrm{DPPH})$, butylated hydroxytoluene $(\mathrm{BHT})$, vitamin $\mathrm{E}(\alpha-$ tocopherol), gallic acid, quercetin, potassium ferricyanide, ferric chloride, ammonium molybdate, acetylcholinesterase (AChE), tacrine, $\alpha$-amylase, acarbose, penicillin, FolinCiocalteu phenol reagent, and HPLC grade reagents: quinic acid, caffeic acid, protocatechuic acid, 1,3-di-O-caffeoylquinic acid, 3,4-di-O-caffeoylquinic acid, 4,5-di-O-caffeoylquinic acid, apigenin-7-O-glucoside, cirsilineol, and acacetin were purchased from Merck (Sigma-Aldrich, Steinheim, Germany).

2.3. Extraction Procedure. Air-dried and powdered aerial part (300 g) of $V$. lippii was extracted by maceration with $80 \%$ aqueous-ethanol for 24 hours three times at room temperature with regular stirring. The resulting extracts were collected, filtered, and concentrated under vacuum. The dried crude extract was solubilized in $500 \mathrm{~mL}$ of distilled water for fractionation. The aqueous solution was further partitioned successively with hexane, dichloromethane, ethyl acetate, and n-butanol. The hexane, dichloromethane, ethyl acetate, nbutanol, and the final aqueous fractions were filtered and evaporated to dryness under vacuum.

2.4. Determination of Total Phenolic Content. The total phenolic content in $V$. lippii extracts was estimated by FolinCiocalteu method according to Chen et al. [12]. To $100 \mu \mathrm{L}$ of diluted sample extract, $2 \mathrm{~mL}$ of $\mathrm{Na}_{2} \mathrm{CO}_{3}$ aqueous solution (2\%) and $100 \mu \mathrm{L}$ of $50 \%$ Folin-Ciocalteu reagent were added.
The final mixture was incubated for 30 minutes in the dark. The absorbance of each sample was read at $750 \mathrm{~nm}$ with a Shimadzu UV/Vis spectrophotometer (Jenway 6320D). The results are expressed in gallic acid equivalents (mg GAE/g extract).

2.5. Determination of Total Flavonoid Content. The total flavonoid content in extracts was determined by the method described previously by Djeridane et al. [13] and expressed as quercetin equivalents ( $\mathrm{mg} \mathrm{QE} / \mathrm{g}$ extract). Briefly, $1 \mathrm{~mL}$ of each diluted $V$. lippii fraction was added to $1 \mathrm{~mL}$ of $\mathrm{AlCl}_{3}$ methanolic solution (2\%). After $15 \mathrm{~min}$ incubation at room temperature, the absorbance of the obtained mixture was measured at $430 \mathrm{~nm}$.

2.6. DPPH Radical Scavenging Assay. The DPPH radical scavenging activity of different fractions of $V$. lippii was evaluated following the procedure described by Les et al. [14]. $\mathrm{IC}_{50}$ value of each fraction, i.e., concentration of sample necessary to decrease the initial DPPH concentration by $50 \%$, is a parameter widely used to assess the antioxidant activity. Briefly, 1.5 $\mathrm{mL}$ of DPPH solution $\left(10^{-4} \mathrm{M}\right.$, in $95 \%$ Ethanol) was added to $1.5 \mathrm{~mL}$ of each $V$. lippii fraction at various concentrations $(0.01-1 \mathrm{mg} / \mathrm{mL})$. The final concentrations in the reaction's mixture were $0.005-0.5 \mathrm{mg} / \mathrm{mL}$. Each mixture was shaken and allowed in the dark for $30 \mathrm{~min}$ at room temperature. The blank was prepared as above without any extract and the BHT was used as positive control. The percentage of inhibition (PI (\%)) was determined spectrophotometrically by monitoring the decrease in absorbance at $517 \mathrm{~nm}$ against a blank. The PI was calculated using the following equation:

$$
\operatorname{PI}(\%)=\left[\frac{\mathrm{A}_{\text {blank }}-\mathrm{A}_{\text {sample }}}{\mathrm{A}_{\text {blank }}}\right] \times 100
$$

where $A_{\text {blank }}$ is the absorbance of the blank and $A_{\text {sample }}$ is the absorbance of the test sample.

The calibration curve for scavenging percentage against extract concentration was plotted and the $\mathrm{IC}_{50}$ (half maximal inhibitory concentration) value of each sample was established.

2.7. Total Antioxidant Capacity Assay (TAC). The total antioxidant capacity (TAC) of all fractions of $V$. lippii was spectrophotometrically assessed by the method of Prieto et al. [15]. A $0.1 \mathrm{~mL}$ of each $V$. lippii fraction $(1 \mathrm{mg} / \mathrm{mL})$ was mixed with $1 \mathrm{~mL}$ of reagent solution $(28 \mathrm{mM}$ sodium phosphate, $0.6 \mathrm{M}$ sulfuric acid and $4 \mathrm{mM}$ ammonium molybdate). The mixtures were incubated for $90 \mathrm{~min}$ in a boiling water bath at $95^{\circ} \mathrm{C}$. After cooling the samples, the absorbance was determined at $695 \mathrm{~nm}$. The antioxidant capacity was expressed as equivalents of vitamin $\mathrm{E}(\mu \mathrm{g} / \mathrm{g}$ of extract).

2.8. Reducing Power Assay. The reducing power of all fractions was evaluated using the procedure of Yildirim et al. [16], and BHT was used as positive control. A $1 \mathrm{~mL}$ of different concentrations of each $V$. lippii sample $(5,10,25,50,100$ $\mu \mathrm{g} / \mathrm{mL}$ ) was mixed with $2.5 \mathrm{~mL}$ of $1 \%$ potassium ferricyanide 
and $2.5 \mathrm{~mL}$ of sodium phosphate buffer $(0.2 \mathrm{M}, \mathrm{pH}=6.6)$. The mixture was incubated for $20 \mathrm{~min}$ at $50^{\circ} \mathrm{C}$ and then $2.5 \mathrm{~mL}$ of $10 \%$ trichloroacetic acid were added and centrifuged for 10 minutes. $2.5 \mathrm{~mL}$ of the supernatant were mixed with $0.5 \mathrm{~mL}$ of ferric chloride solution $(0.1 \%)$ and $2.5 \mathrm{~mL}$ of distilled water. The absorbance of the mixture was measured at $700 \mathrm{~nm}$.

2.9. Determination of Acetylcholinesterase (AChE) Inhibitory Activity. The AChE inhibitory activity was performed according to the colorimetric method described by Ellman et al. [17], with modifications. Briefly, $125 \mu \mathrm{L}$ of DTNB (3 mM), $50 \mu \mathrm{L}$ of sodium phosphate buffer ( $\mathrm{pH} 8.0$ ), $25 \mu \mathrm{L}$ of AChE $(0.5 \mathrm{U} / \mathrm{mL})$, and $25 \mu \mathrm{L}$ of each $V$. lippii extract dissolved in DMSO were added in a 96-well microplate and incubated for $15 \mathrm{~min}$ at $25^{\circ} \mathrm{C}$. The reaction was then initiated by the addition of $25 \mu \mathrm{L}$ of acetylthiocholine iodide (ATCI) and the hydrolysis of acetylthiocholine iodide was controlled by the formation of the yellow 5-thio-2-nitrobenzoate anion as a result of the reaction of thiocholine with DTNB. Plant fractions were tested for AChE inhibitory activity at the following concentrations $25,50,125,250$, and $500 \mu \mathrm{g} / \mathrm{mL}$. The final concentrations in the reaction's mixture were $2.5,5$, $12.5,25$, and $50 \mu \mathrm{g} / \mathrm{mL}$ [14]. A reaction mixture containing all the components except the $V$. lippii extract was used as control. Tacrine was used as positive control. The absorbance was then read three times with 3 min intervals at $405 \mathrm{~nm}$ by a CERES UV 900C microplate reader (Bio-Tek Instrument, USA). Any increase in absorbance due to the spontaneous hydrolysis of the substrate was revised by subtracting the absorbance before appending the enzyme. The percentage inhibition was calculated as follows:

$$
\mathrm{PI}(\%)=\left[\frac{\mathrm{A}_{\text {control }}-\mathrm{A}_{\text {sample }}}{\mathrm{A}_{\text {control }}}\right] \times 100
$$

where $A_{\text {control }}$ is the absorbance of the control and $A_{\text {sample }}$ is the absorbance of the test sample.

Extract concentration providing 50\% inhibition $\left(\mathrm{IC}_{50}\right)$ was obtained by plotting the percentage inhibition against extract concentration.

2.10. Determination of $\alpha$-Amylase Activity In Vitro. The in vitro $\alpha$-amylase inhibitory assay of all fractions was performed by the previous method described by Gella et al. [18]. The enzyme $\alpha$-amylase solution was made by blending 3.246 $\mathrm{mg}$ of alpha amylase (EC 3.2.1.1) in $100 \mathrm{~mL}$ of phosphate buffer $(40 \mathrm{mM}, \mathrm{pH} 6.9$ ). The assays were conducted by mixing $30 \mu \mathrm{L}$ of alpha-amylase solution, $120 \mu \mathrm{L}$ of E-PNPG7, and $60 \mu \mathrm{L}$ of each $V$. lippii fraction in the concentration range 25,50 , and $100 \mu \mathrm{g} / \mathrm{mL}$. The final concentrations in the reaction's mixture were $7.14,14.28$, and $28.57 \mu \mathrm{g} / \mathrm{mL}$. The positive control (acarbose) was prepared by dissolving $50 \mathrm{mg}$ in $50 \mathrm{~mL}$ of phosphate buffer and diluted to get different concentrations 10,20 , and $40 \mu \mathrm{g} / \mathrm{mL}$. The final concentrations in the reaction's mixture were $2.85,5.71$, and $11.42 \mu \mathrm{g} / \mathrm{mL}$. The mixture was incubated for $8 \mathrm{~min}$ at $37^{\circ} \mathrm{C}$. The absorbance was read at $405 \mathrm{~nm}$ and control reaction was carried out without the $V$. lippii fractions. Percentage inhibition (PI) was calculated by the following expression:

$$
\mathrm{PI}(\%)=\left[\frac{\mathrm{A}_{\text {control }}-\mathrm{A}_{\text {sample }}}{\mathrm{A}_{\text {control }}}\right] \times 100
$$

where $\mathrm{A}_{\text {control }}$ is the absorbance of the control and $\mathrm{A}_{\text {sample }}$ is the absorbance of the test sample.

2.11. Antimicrobial Activity Assay. The V. lippii fractions were assessed against a five bacterial strains: Gram-negative: Salmonella enterica (CIP 8039) and Escherichia coli (ATCC 8739), Gram-positive: Staphylococcus aureus (ATCC 6538), Bacillus thuringiensis, and Enterococcus faecalis (ATCC 29212). Bacteria not obtained from an ATCC collection were acquired from the Microbiology Department, Faculty of Science, University of Sfax (Tunisia). Bacterial strains were cultured in Mueller-Hinton agar (MHA) for $24 \mathrm{~h}$ at $37^{\circ} \mathrm{C}$.

The disc diffusion method was employed for the determination of antibacterial activities of $V$. lippii fractions according to the method described by Berghe and Vlietinck [19]. Antibacterial activities were evaluated by measuring the diameters of the inhibition zones against the test organisms and compared to penicillin (10 $\mu \mathrm{g}$ per disk) as the positive control. Tests were carried out in triplicate.

2.12. Chromatographic Conditions and Apparatus. HPLC procedures chromatographic separation was performed on Aquasil C18 (Thermo Electron, Dreieich, Germany) column (150 $\mathrm{mm} \times 3 \mathrm{~mm}, 3 \mu \mathrm{m}$ particle size). The solvents used were (A) $0.1 \%$ formic acid in water and (B) $0.1 \%$ formic acid in methanol. The elution gradient established was 10 $100 \% \mathrm{~B}, 0-45 \mathrm{~min} ; 100 \% \mathrm{~B}, 45-55 \mathrm{~min}$ and reequilibration duration was $5 \mathrm{~min}$ between individual runs. The flow rate of the mobile phase was $0.4 \mathrm{~mL} / \mathrm{min}$, the injection volume was $5 \mu \mathrm{L}$, and the column temperature was maintained at $40^{\circ} \mathrm{C}$. Phenolics present in the fractions were characterized according to their retention times, UV and mass spectra compared with commercial standards when available. The quantification of phenolics was determined based on DAD results, using $280 \mathrm{~nm}$ for the phenolic acids and 320 and 370 $\mathrm{nm}$ for flavonoids.

The LC-ESI-MS/MS analysis was carried out using a LCMS-8030 triple quadrupole mass spectrometer (Shimadzu, Kyoto, Japan) equipped with an electrospray ionization (ESI). The mass spectrometer was operated in negative ion mode with a nebulizing gas flow of $1.5 \mathrm{~L} / \mathrm{min}$, a dry gas flow rate of $12 \mathrm{~L} / \mathrm{min}$, a block source temperature of $400^{\circ} \mathrm{C}$, a DL (dissolving line) temperature of $250^{\circ} \mathrm{C}$, the full scan spectra from 50 to $2000 \mathrm{Da}$, and the negative ionization mode source voltage $-4500 \mathrm{~V}$.

2.13. Statistical Analyses. Each calculation was accomplished using SPSS software (version 19.0; SPSS Inc., Chicago, IL, USA). All experiments were carried out as means \pm standard deviations of three replicates. Analysis of variance (ANOVA) followed by Tukey's post hoc test were used to establish the differences between means of various groups. The level of 
significance was fixed at $\mathrm{P}<0.05$. The principal component analysis (PCA) was applied to separate ethyl acetate and water extracts according to all the parameters investigated without any rotation. The biplot type was correlation biplot, the PCA type was Pearson (n), and the coefficient was automatic. The PCA plots and the Pearson correlation matrix were achieved using XLSTAT software for Windows (v.2014.1.08, Add in soft, New York, USA).

\section{Results and Discussion}

3.1. Total Phenolic and Flavonoid Contents. The total phenolic (TP) and total flavonoid (TF) contents of different studied fractions from $V$. lippii were determined. As can be seen in Table 1, the levels of phenolic compounds varied significantly $(\mathrm{p}<0.05)$ depending on the influence of solvent polarity [20] and have been found to be rich in all fractions except the hexane one. The ethyl acetate fraction showed the highest $(\mathrm{p}<0.05)$ amount of phenolic compounds $(65.22 \pm 0.03 \mathrm{mg}$ GAE/g) followed by the n-butanol (38.83 $\pm 0.07 \mathrm{mg}$ GAE/g), the aqueous $(35.04 \pm 0.05 \mathrm{mg} \mathrm{GAE} / \mathrm{g})$, the dichloromethane $(24.13 \pm 0.04 \mathrm{mg} \mathrm{GA} / \mathrm{g})$, and the hexane $(7.46 \pm 0.23 \mathrm{mg}$ $\mathrm{GAE} / \mathrm{g}$ ) fractions.

With regard to the TF, the highest $(\mathrm{p}<0.05)$ value was also found in the ethyl acetate fraction $(12.50 \pm 0.04 \mathrm{mg}$ $\mathrm{QE} / \mathrm{g})$, whereas the lower $(\mathrm{p}<0.05)$ one was observed in the hexane fraction $(2.14 \pm 0.05 \mathrm{mg} \mathrm{QE} / \mathrm{g})$. These findings were in agreement with those revealed by Karamenderes et al. (2007) for eight different species of Centaurea (synonym of Volutaria) [21].

3.2. Antioxidant Activity. Several studies were devoted to finding natural antioxidants such as phenolic compounds and flavonoids, which are principally responsible for the antioxidant properties of plant $[22,23]$. The antioxidant capacity of different plant extracts cannot be evaluated by a single testing method due to the complex nature of phytochemicals [24]. For this reason, three complementary in vitro chemical assays, in terms of DPPH radical scavenging, reducing power, and total antioxidant capacity, were applied in order to screen the potential antioxidant properties of $V$. lippii extracts.

3.2.1. DPPH Radical Scavenging Assay. Antioxidant activity in food can be expressed in terms of radical scavenging ability using free radicals. DPPH assay is extensively used to determine the antioxidant property of many plant extracts $[25,26]$. It is well known that free radicals have an important role in the autoxidation of unsaturated lipids in foodstuffs and in oxidative cell damage in the human organism resulting in a variety of pathological diseases [27]. Antioxidants can intercept the chain autoxidation of lipids and donate hydrogen to free radicals, particularly to the lipid peroxides radicals, thereby forming stable free radicals, which do not initiate or propagate further lipid oxidation [28]. The DPPH scavenging activity of $V$. lippii fractions, expressed as $\mathrm{IC}_{50}(\mu \mathrm{g} / \mathrm{mL})$, were illustrated in Table 1. Obtained results demonstrated that $\mathrm{IC}_{50}$ of different fractions ranged from $11.50 \pm 0.57$ to $43.77 \pm 2.09 \mu \mathrm{g} / \mathrm{mL}$, indicating their antioxidant potentials compared with the standard BHT $(13.00 \pm 0.57 \mu \mathrm{g} / \mathrm{mL})$. The order of DPPH scavenging ability of fractions and BHT was as follows: ethyl acetate (11.50 $\pm 0.57 \mu \mathrm{g} / \mathrm{mL})>$ BHT $(13.00 \pm 0.57 \mu \mathrm{g} / \mathrm{mL})>$ aqueous $(28.81$ $\pm 1.35 \mu \mathrm{g} / \mathrm{mL})>$ dichloromethane $(34.25 \pm 1.69 \mu \mathrm{g} / \mathrm{mL})>\mathrm{n}$ butanol $(43.77 \pm 2.09 \mu \mathrm{g} / \mathrm{mL})$. The hexane fraction was found inactive.

These results proposed that the tested fractions, especially ethyl acetate and aqueous ones, have a good capability to donate electrons to reactive free radicals converting them into more stable forms [22]. The raised free radical scavenging activity of $V$. lippii is in favour of the implication of phenolic compounds which have been quantified in all its fractions (Table 1).

3.2.2. Total Antioxidant Capacity Assay (TAC). CAT method offers a broader view of the antioxidant potential of plant extracts and expresses different aspects of antioxidant action [25]. The results depicted in Table 1 showed that the ethyl acetate fraction has the highest $(\mathrm{P}<0.05)$ antioxidant capacity (105.21 $\pm 0.01 \mathrm{mg}$ vitamin $\mathrm{E} / \mathrm{g}$ extract) that can be related to its high levels in TP and TF. The TAC of $V$. lippii extracts was found to increase in the following order: hexane < dichloromethane $<$ n-butanol $<$ aqueous $<$ ethyl acetate. This result is in good accordance with the phenolic content variation in all fractions.

3.2.3. Reducing Power Assay (FRAP). The reducing powers of testing fractions and BHT were also determined (Table 1). In this test, all fractions presented dose-dependent activity whose results are lower than that of $\mathrm{BHT}\left(\mathrm{EC}_{50}=\right.$ $43.35 \pm 0.95 \mu \mathrm{g} / \mathrm{mL}$ ). In fact, reducing power of $V$. lippii fractions increased and was well correlated when concentration increased. The reducing power was expressed as effective concentration $\mathrm{EC}_{50}$ at which the absorbance is 0.5 . As indicated in Table 1, the results revealed that the ethyl acetate fraction exhibited the highest $(\mathrm{P}<0.05)$ activity $\left(\mathrm{EC}_{50}=55.40 \pm 2.00\right.$ $\mu \mathrm{g} / \mathrm{mL})$, followed by aqueous $\left(\mathrm{EC}_{50}=66.65 \pm 1.40 \mu \mathrm{g} / \mathrm{mL}\right), \mathrm{n}-$ butanol $\left(\mathrm{EC}_{50}=150.0 \pm 3.12 \mu \mathrm{g} / \mathrm{mL}\right)$, dichloromethane $\left(\mathrm{EC}_{50}=\right.$ $216.66 \pm 2.49 \mu \mathrm{g} / \mathrm{mL})$, and hexane $\left(\mathrm{EC}_{50}=383.33 \pm 2.85 \mu \mathrm{g} / \mathrm{mL}\right)$ fractions.

These reducing properties are often due to the presence of reductones capable of exerting an antioxidant effect by breaking the free radicals chain and by donating a hydrogen atom. It was reported that reductones respond to various precursors of peroxides and therefore prevent their generation [29].

The results obtained with the three antioxidant activity tests revealed that the different plant extracts contained a considerable amount of antioxidant components. Differences in solvent polarities and thus different extractability of the antioxidant components may explain the differences in the antioxidant activity of $V$. lippii extracts. Both ethyl acetate and aqueous fractions have the strongest antioxidant effects that are related to their high levels of phenolic and flavonoid contents (Table 1). Thus, V. lippii extracts, especially ethyl acetate, could be used as natural antioxidant agents. 


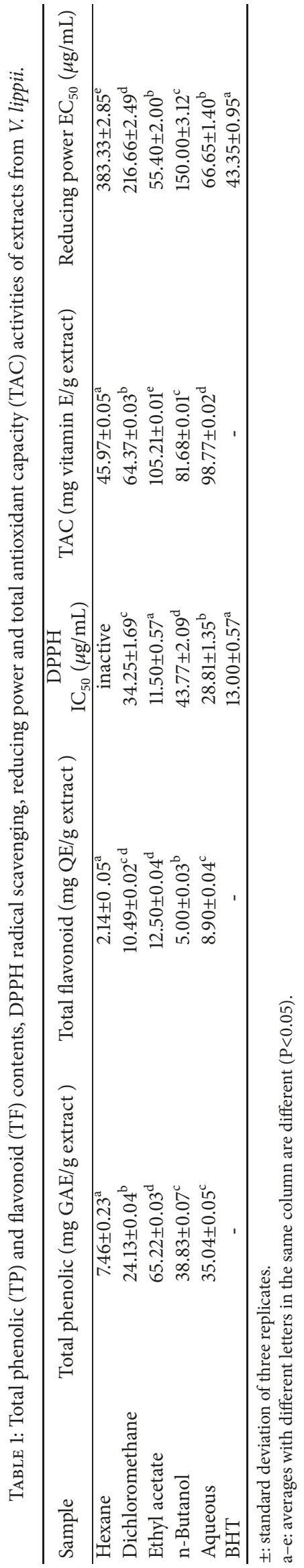


TABLE 2: Acetylcholinesterase inhibitory activity of V. lippii extracts.

\begin{tabular}{lc}
\hline Sample & $\mathrm{IC}_{50}(\mu \mathrm{g} / \mathrm{mL})$ \\
\hline Hexane & inactive \\
Dichloromethane & $15.78 \pm 0.78^{\mathrm{c}}$ \\
Ethyl acetate & $17.76 \pm 0.88^{\mathrm{d}}$ \\
n-Butanol & $9.97 \pm 0.48^{\mathrm{b}}$ \\
Aqueous & $3.91 \pm 0.19^{\mathrm{a}}$ \\
Tacrine & $3.50 \pm 0.17^{\mathrm{a}}$ \\
\hline
\end{tabular}

\pm : standard deviation of three replicates.

a-d: averages with different letters in the same column are different $(\mathrm{P}<0.05)$.

\subsection{Acetylcholinesterase Enzyme (AChE) Inhibitory Activity.} The results related to the AChE inhibitory activity of $V$. lippii extracts are given in Table 2. Only aqueous extract gave a strong $\mathrm{AChE}$ inhibition $(\mathrm{P}<0.05)$ with $\mathrm{IC}_{50}$ value of $3.91 \pm$ $0.19 \mu \mathrm{g} / \mathrm{mL}$ when compared to the tacrine $\left(\mathrm{IC}_{50}=3.50 \pm 0.17\right.$ $\mu \mathrm{g} / \mathrm{mL})$ used as a standard of AChE inhibition. The n-butanol $\left(\mathrm{IC}_{50}=9.97 \pm 0.48 \mu \mathrm{g} / \mathrm{mL}\right)$, dichloromethane $\left(\mathrm{IC}_{50}=15.78 \pm\right.$ $0.78 \mu \mathrm{g} / \mathrm{mL})$, and ethyl acetate $\left(\mathrm{IC}_{50}=17.76 \pm 0.88 \mu \mathrm{g} / \mathrm{mL}\right)$ extracts showed moderate AChE inhibitory activity. However, the hexane fraction exhibited no inhibition, and its activity was same as that of control. These results reveal that the active fractions were those obtained by extraction with polar solvents (aqueous and n-butanol). In comparison with other studies, the aqueous extract of $V$. lippii exhibited AChE inhibitory activity higher than that obtained from aqueous extracts of some plants from Argentina [30] and some Centaurea species such as C. antalyense, C. polypodiifolia var. pseudobehen, and C. pyrrhoblephara [31].

AChE inhibitors have been extensively used in the treatment of mild to moderate Alzheimer disease. There are several researchers who focused on the quest of new AChE inhibitors from the herbal resources to replace synthetic drugs such as donepezil and tacrine having any adverse effects [32]. For this purpose, the obtained results indicate that $V$. lippii could serve as an inhibitor against the cholinesterase enzyme family and used as complement for the treatment of some Alzheimer diseases. The AChE inhibitory activity of $V$. lippii extracts has never been reported before and their anticholinesterase activity could be attributed to their TP and TF contents (Table 1). Indeed, several authors reported previously a strong relationship between anticholinesterase activity and phenolic content of some Centaurea species such as C. depressa, C. drabifolia subsp. Detonsa, C. kotschyi var. persica, C. patula, C. pulchella, C. tchihatcheffi, C. triumfettii, and C. urvillei subsp. Hayekiana $[31,33]$.

3.4. In Vitro Alpha-Amylase Inhibitory Assay. This assay evaluated the ability of $V$. lippii extracts to inhibit $\alpha$-amylase activity. The $\alpha$-amylase, a digestive enzyme secreted from the pancreas and salivary gland, is engaged in important biological processes such as digestion of carbohydrates, reducing postprandial hyperglycaemia. The inhibition of this digestive enzyme is therefore used as one of the diabetic treatments [23]. As indicated in Table 3, the $\mathrm{IC}_{50}$ values of aqueous, nbutanol, ethyl acetate, and dichloromethane fractions were
$7.48 \pm 0.34,11.07 \pm 0.56,13.28 \pm 0.65$, and $16.99 \pm 0.81 \mu \mathrm{g} / \mathrm{mL}$, respectively, indicating their promising inhibitory activity against the pancreatic $\alpha$-amylase enzyme. It should be noted that acarbose (standard antidiabetic agent) showed more potent inhibition of $\alpha$-amylase $\left(\mathrm{IC}_{50}=5.54 \pm 0.27 \mu \mathrm{g} / \mathrm{mL}\right.$ ) than all tested fractions.

Moreover, the appreciable $\alpha$-amylase inhibitory capacities of these fractions might be attributed to their TP values (Table 1). This suggestion was in agreement with previous studies reporting that many phenolic compounds and flavonoids could prevent the activity of carbohydratehydrolyzing enzymes, related to their capacity to bind with proteins $[25,29]$. Therefore, $V$. lippii can be considered a new natural source able to fight against type 2 diabetes.

3.5. Antibacterial Activity Assay. In the present study, the antibacterial activity of $V$. lippii fractions was evaluated through a set of pathogenic bacteria. The relevant results of this assay were depicted in Table 4. The V. lippii extracts inhibited the growth of bacterial strains producing a zone diameter of inhibition from 5.0 to $17.6 \mathrm{~mm}$ for Gramnegative bacteria and from 5.25 to $15.5 \mathrm{~mm}$ for Grampositive bacteria. The standard antibiotic, penicillin, showed a strong antibacterial inhibition against practically all bacteria strains. Among Gram-negative bacteria, the strongest activity was observed $(\mathrm{p}<0.05)$ for aqueous and $\mathrm{n}$-butanol fractions against Salmonella enterica $(17.6 \pm 0.5 \mathrm{~mm}$ and $14.0 \pm 0.3 \mathrm{~mm}$, respectively). These values are higher $(\mathrm{p}<0.05)$ than that of penicillin, which is sensitive to the bacteria. Generally, plant extracts were usually more active against Gram-positive than Gram-negative bacteria [25]. This could be explained by the fact that Gram-positive strains have only a peptidoglycan layer which is not a selective barrier to plant extracts [26]. The antibacterial activity of $V$. lippii could be assigned to the presence of a high concentration of phenolic compounds which were reported in previous works to exhibit a powerful antimicrobial effect $[22,26]$.

3.6. Activities Discrimination of Ethyl Acetate and Water Fractions by Combining Phytochemical Contents within a Multivariate Analysis: Principal Component Analysis. Principal Component Analysis (PCA) was conducted to get a general overview of the data distribution, thus a new set of latent factors or principal components (PCs) was generated. In this part, PCA based on the corresponding data of ethyl acetate and water fractions set including chemical (total phenolic and flavonoid contents), antioxidant (DPPH radical scavenging assay, total antioxidant capacity assay (TAC) and reducing power assay (FRAP)), alpha-amylase inhibitory assay, antimicrobial and acetylcholinesterase enzyme (AChE) inhibitory values of ethyl acetate and water fractions values was carried out (Figure 1).

The first principal component (PC1) had the highest eigenvalue of 5.89 and accounted for $54.36 \%$ of the variability in the data set. The second, third, and fourth PCs (PC2, PC3, and PC4) had eigenvalues of 2.851, 1.328, and 0.841 and explained $25.921 \%, 12.075 \%$, and $7.641 \%$ of the variance in the data, respectively. Subsequently, plotting the scores 
TABle 3: Pancreatic $\alpha$-amylase inhibition assay of $V$. lippii extracts.

\begin{tabular}{|c|c|c|c|}
\hline Sample & Concentration $(\mu \mathrm{g} / \mathrm{mL})$ & \% Inhibition & $\mathrm{IC}_{50}(\mu \mathrm{g} / \mathrm{mL})$ \\
\hline \multirow{3}{*}{ Hexane } & 28.57 & $44.50 \pm 0.08^{\mathrm{c}}$ & \multirow{3}{*}{ inactive } \\
\hline & 14.28 & $32.54 \pm 0.11^{\mathrm{b}}$ & \\
\hline & 7.14 & $17.67 \pm 0.06^{\mathrm{a}}$ & \\
\hline \multirow{3}{*}{ Dichloromethane } & 28.57 & $88.23 \pm 0.09^{c}$ & \multirow{3}{*}{$16.99 \pm 0.81^{\mathrm{e}}$} \\
\hline & 14.28 & $46.55 \pm 0.03^{\mathrm{b}}$ & \\
\hline & 7.14 & $32.83 \pm 0.08^{\mathrm{a}}$ & \\
\hline \multirow{3}{*}{ Ethyl acetate } & 28.57 & $90.02 \pm 0.10^{c}$ & \multirow{3}{*}{$13.28 \pm 0.65^{\mathrm{d}}$} \\
\hline & 14.28 & $62.73 \pm 0.13^{\mathrm{b}}$ & \\
\hline & 7.14 & $38.36 \pm 0.09^{\mathrm{a}}$ & \\
\hline \multirow{3}{*}{ n-Butanol } & 28.57 & $92.13 \pm 0.02^{c}$ & \multirow{3}{*}{$11.07 \pm 0.56^{\mathrm{c}}$} \\
\hline & 14.28 & $67.44 \pm 0.05^{\mathrm{b}}$ & \\
\hline & 7.14 & $40.54 \pm 0.11^{\mathrm{a}}$ & \\
\hline \multirow{3}{*}{ Aqueous } & 28.57 & $94.70 \pm 0.12^{c}$ & \multirow{3}{*}{$7.48 \pm 0.34^{\mathrm{b}}$} \\
\hline & 14.28 & $74.13 \pm 0.09^{\mathrm{b}}$ & \\
\hline & 7.14 & $48.16 \pm 0.10^{\mathrm{a}}$ & \\
\hline \multirow{3}{*}{ Acarbose } & 11.42 & $86.62 \pm 0.04^{c}$ & \multirow{3}{*}{$5.54 \pm 0.27^{\mathrm{a}}$} \\
\hline & 5.71 & $51.52 \pm 0.02^{\mathrm{b}}$ & \\
\hline & 2.85 & $29.80 \pm 0.07^{\mathrm{a}}$ & \\
\hline
\end{tabular}

\pm : standard deviation of three replicates.

a-e: averages with different letters in the same column are different $(\mathrm{P}<0.05)$.

TABLE 4: Antibacterial activity of $V$. lippii extracts using agar disc diffusion method.

\begin{tabular}{lccccc}
\hline Sample & $\begin{array}{c}\text { Salmonella enterica } \\
\text { CIP 8039 }\end{array}$ & $\begin{array}{c}\text { Escherichia coli } \\
\text { ATCC 8739 }\end{array}$ & $\begin{array}{c}\text { Enterococcus faecalis } \\
\text { ATCC29212 }\end{array}$ & $\begin{array}{c}\text { Staphylococcus aureus } \\
\text { ATCC 6538 }\end{array}$ & Bacillus thuringiensis \\
\hline Hexane & $7.33 \pm 0.3^{\mathrm{a}}$ & $5.25 \pm 0.1^{\mathrm{a}}$ & $5.25 \pm 0.1^{\mathrm{a}}$ & $5.25 \pm 0.1^{\mathrm{a}}$ & $8.33 \pm 0.3^{\mathrm{b}}$ \\
Dichloromethane & $9.25 \pm 0.5^{\mathrm{b}}$ & $7.8 \pm 0.6^{\mathrm{b}}$ & $5.75 \pm 0.2^{\mathrm{a}}$ & $5.0 \pm 0.1^{\mathrm{a}}$ & $5.83 \pm 0.2^{\mathrm{a}}$ \\
Ethyl acetate & $10.5 \pm 0.4^{\mathrm{b}}$ & $5.0 \pm 0.2^{\mathrm{a}}$ & $6.33 \pm 0.2^{\mathrm{a}}$ & $5.33 \pm 0.1^{\mathrm{a}}$ & $5.5 \pm 0.1^{\mathrm{a}}$ \\
n-Butanol & $14.0 \pm 0.3^{\mathrm{c}}$ & $12.0 \pm 0.4^{\mathrm{c}}$ & $5.50 \pm 0.1^{\mathrm{a}}$ & $15.4 \pm 0.3^{\mathrm{c}}$ & $5.0 \pm 0.2^{\mathrm{a}}$ \\
Aqueous & $17.6 \pm 0.5^{\mathrm{d}}$ & $12.2 \pm 0.1^{\mathrm{c}}$ & $8.40 \pm 0.32^{\mathrm{b}}$ & $10.5 \pm 0.6^{\mathrm{b}}$ & $15.5 \pm 0.3^{\mathrm{c}}$ \\
Penicillin & $\mathrm{R}$ & $16.3 \pm 0.1^{\mathrm{d}}$ & $16.0 \pm 0.2^{\mathrm{c}}$ & $14.1 \pm 0.5^{\mathrm{c}}$ & $18.0 \pm 0.4^{\mathrm{d}}$ \\
\hline
\end{tabular}

$\mathrm{R}=$ resistant. Inhibition zone in diameter $(\mathrm{mm} \pm \mathrm{SD})$ around the discs impregnated with $100 \mu \mathrm{g}$ per disc of each extract. Penicillin $(10 \mu \mathrm{g} / \mathrm{disc})$ was used as positive control for bacteria.

\pm : standard deviation of three replicates.

a-d: averages with different letters in the same column are different $(\mathrm{P}<0.05)$.

of the samples in the subspaces PC1 vs. PC2 (Figure 1) ( $80.28 \%$ of the total variance of the data) a clear grouping of samples was observable based on solvent extraction (ethyl acetate and water). Moreover, the PCA, which confirms the previous observations, allowed the discrimination of two groups around the PC1 and PC2 axes' components and activities (Figure 1). These axes' components selected positively the group G1 with ethyl acetate fraction correlating with TAC, acetylcholinesterase enzyme (AChE), and alphaamylase activities. The group G2 mainly constituted by the water fraction which correlate with DPPH radical scavenging and antibacterial (anti-Salmonella enterica, anti-Escherichia coli, and anti-Staphylococcus aureus) activities.

3.7. Qualitative Phytochemical Analyses of Ethyl Acetate and Aqueous Fractions. LC-ESI-MS/MS analyses were performed to determine for the first time the chemical profiles of ethyl acetate and aqueous fractions exhibiting remarkable biological activities. The HPLC chromatograms at $254 \mathrm{~nm}$ of these two fractions were illustrated in Figure 2.

Eighteen constituents, numbered 1-18, were detected and tentatively identified as belonging to both phenolic acid and flavonoid groups. The structures of all identified compounds are shown in Figure 3. The identification of the phenolic compounds was carried out by mass spectra, comparison with reference compounds and with literature data. Table 5 summarized all the identified peaks with retention times $\left(t_{R}\right)$, UV values $\left(\lambda_{\max }\right)$, pseudomolecular ions, molecular formula, and main fragment ions.

3.7.1. Quinic Acid Derivatives. The quinic acid derivatives exhibited characteristic UV spectra with an absorption maxima at $\lambda_{\max }$ around 320-325nm [34]. Peak $1\left(t_{\mathrm{R}} 6.21\right.$ min) was identified as quinic acid by comparison with a 


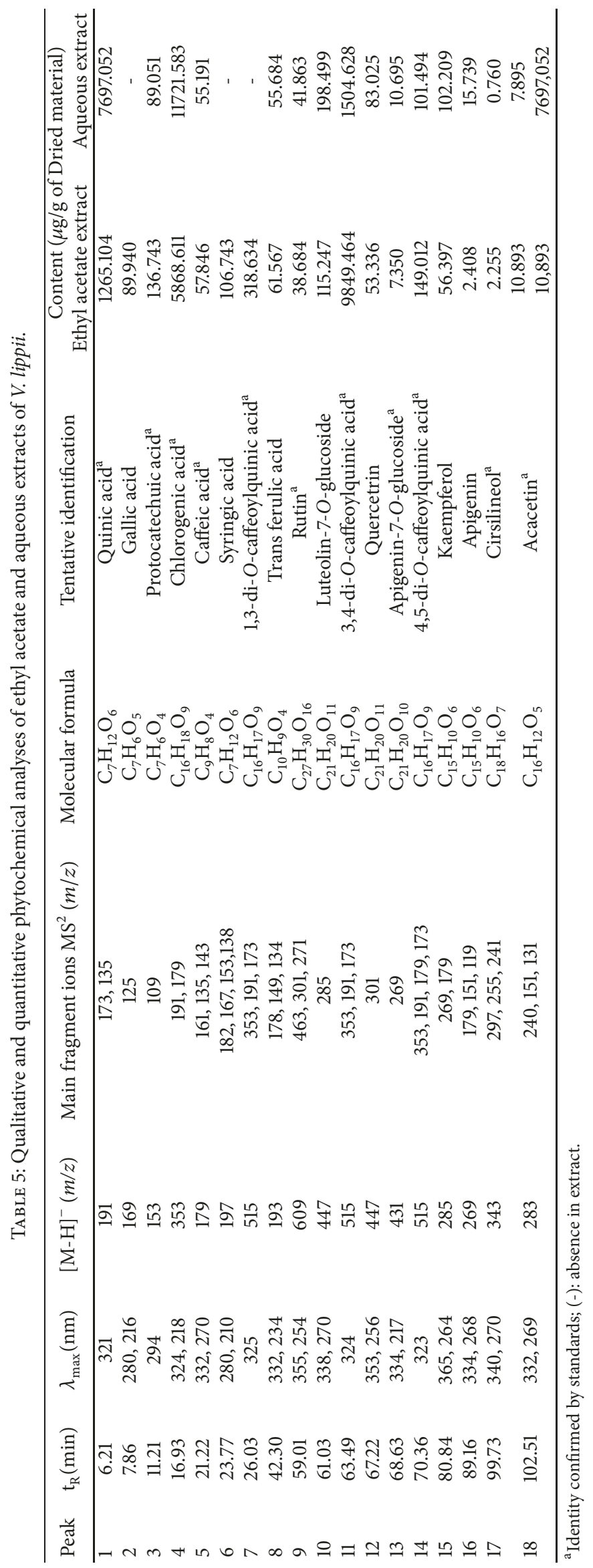




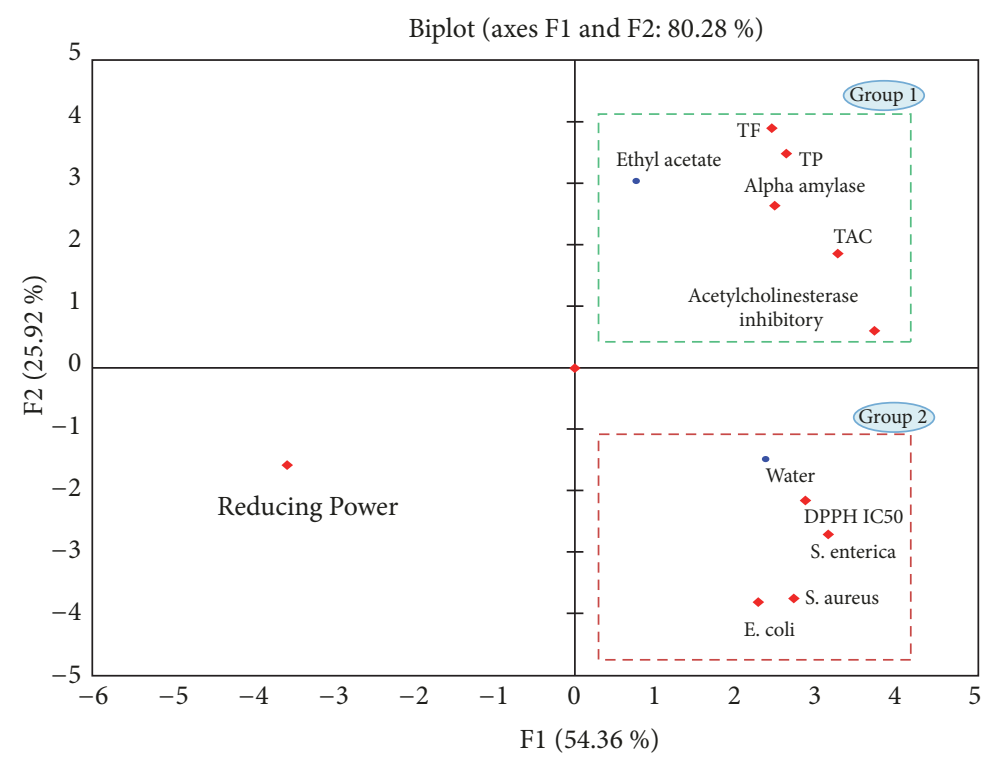

- Active variables

- Active observations

FIGURE 1: Bioplot representation on the factor-plane (PC1-PC2) showing vector distribution of phytochemical content and activities within score plot of the ethyl acetate and aqueous extracts.

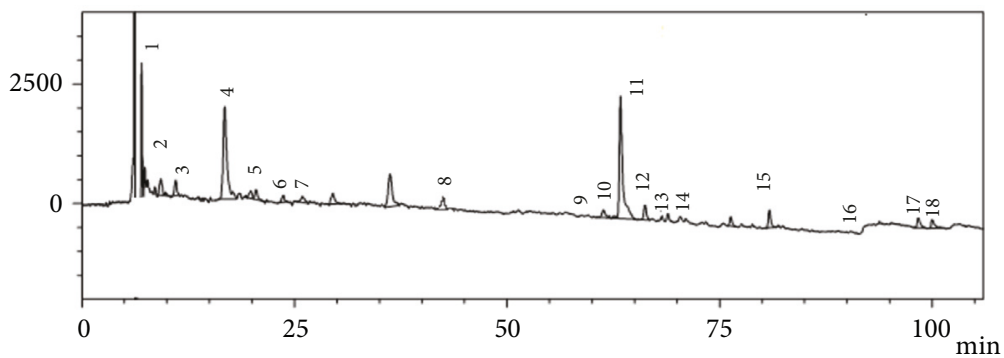

(a)

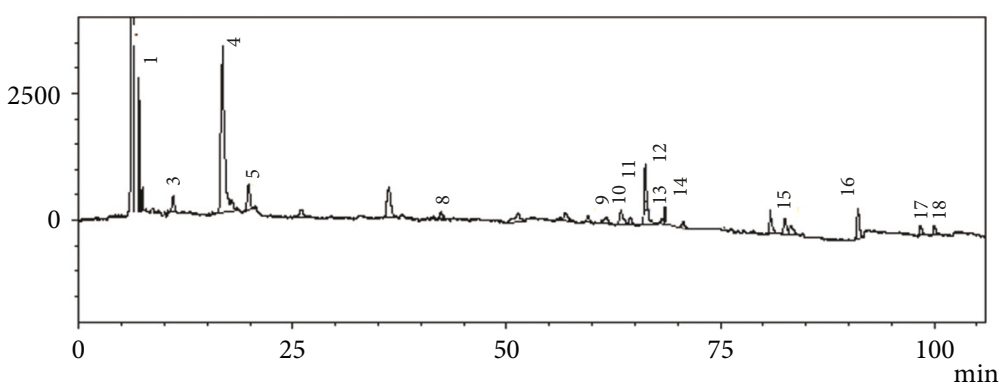

(b)

FIGURE 2: HPLC based peak chromatograms (at $254 \mathrm{~nm}$ ) of components from ethyl acetate (a) and aqueous (b) extracts of V. lippii.

standard and also by its pseudomolecular ion $[\mathrm{M}-\mathrm{H}]^{-}$at $\mathrm{m} / \mathrm{z} 191$ and fragmentation pattern at $\mathrm{m} / \mathrm{z} 173$ [quinic acid$\left.\mathrm{H}-\mathrm{H}_{2} \mathrm{O}\right]^{-}$[35]. Peak $4\left(\mathrm{t}_{\mathrm{R}} 16.93 \mathrm{~min}\right)$ was identified as 3$O$-caffeoylquinic acid that was assigned according to the $\mathrm{MS}^{2}$ fragment ions at $\mathrm{m} / \mathrm{z} 191$ [quinic acid- $\left.\mathrm{H}\right]^{-}$and at $\mathrm{m} / \mathrm{z}$ 179 [caffeic acid-H] $^{-}$and by comparison with an authentic compound [36].
Additionally, three di-O-caffeoylquinic acid isomers were characterized by their deprotonated parent ion $[\mathrm{M}-\mathrm{H}]^{-}$at $\mathrm{m} / \mathrm{z} 515$ and by similar fragmentation patterns at $\mathrm{m} / \mathrm{z} 191$

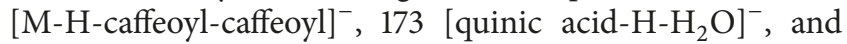
353 [M-H-caffeoyl] ${ }^{-}$characteristics of dicaffeoylquinic acid. However, by comparing the $t_{R}$ of the standard compounds the peaks $7\left(t_{R} 26.03 \mathrm{~min}\right), 11\left(t_{R} 63.49 \mathrm{~min}\right)$, and $14\left(t_{R}\right.$ 


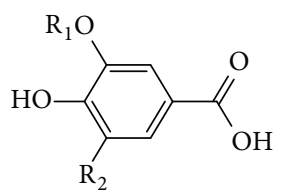

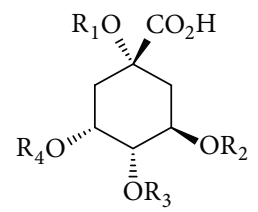<smiles>[R20]c1cc(/C=C/C(=O)[18OH])ccc1O</smiles>

$$
\begin{aligned}
& 2: \mathrm{R}_{1}=\mathrm{H} ; \mathrm{R}_{2}=\mathrm{OH} \\
& 3: \mathrm{R}_{1}=\mathrm{R}_{2}=\mathrm{H} \\
& 6: \mathrm{R}_{1}=\mathrm{CH}_{3} ; \mathrm{R}_{2}=\mathrm{OCH}_{3}
\end{aligned}
$$<smiles>[R20]c1cc(/C=C/C(=O)O)ccc1O</smiles>

$5: \mathrm{R}=\mathrm{H}$

$8: \mathrm{R}=\mathrm{CH}_{3}$<smiles>[R1]c1cc(-c2oc3cc(O)cc(O)c3c(=O)c2OCC)ccc1O</smiles>

9: $\mathrm{R}_{1}=$ rutinosyl group $; \mathrm{R}_{2}=\mathrm{OH}$

$12: \mathrm{R}_{1}=$ rhamnosyl group $; \mathrm{R}_{2}=\mathrm{OH}$

$15: \mathrm{R}_{1}=\mathrm{H} ; \mathrm{R}_{2}=\mathrm{H}$
$1: \mathrm{R}_{1}=\mathrm{R}_{2}=\mathrm{R}_{3}=\mathrm{R}_{4}=\mathrm{H}$

$4: \mathrm{R}_{1}=\mathrm{R}_{3}=\mathrm{R}_{4}=\mathrm{H} ; \mathrm{R}_{2}=$ caffeoyl group

7: $\mathrm{R}_{1}=\mathrm{R}_{2}=$ caffeoyl group $; \mathrm{R}_{3}=\mathrm{R}_{4}=\mathrm{H}$

$11: \mathrm{R}_{1}=\mathrm{R}_{4}=\mathrm{H} ; \mathrm{R}_{2}=\mathrm{R}_{3}=$ caffeoyl group

$14: \mathrm{R}_{1}=\mathrm{R}_{2}=\mathrm{H} ; \mathrm{R}_{3}=\mathrm{R}_{4}=$ caffeoyl group<smiles>[R10]Oc1ccc(-c2cc(=O)c3c(O)c([R2])c(O[R20])cc3o2)cc1[R3]</smiles>

$10: \mathrm{R}_{1}=$ glycosyl group; $\mathrm{R}_{2}=\mathrm{R}_{4}=\mathrm{H} ; \mathrm{R}_{3}=\mathrm{OH}$

13: $\mathrm{R}_{1}=$ glycosyl group; $\mathrm{R}_{2}=\mathrm{R}_{3}=\mathrm{R}_{4}=\mathrm{H}$

$16: \mathrm{R}_{1}=\mathrm{R}_{2}=\mathrm{R}_{3}=\mathrm{R}_{4}=\mathrm{H}$

$17: \mathrm{R}_{1}=\mathrm{CH}_{3} ; \mathrm{R}_{2}=\mathrm{R}_{3}=\mathrm{OCH}_{3} ; \mathrm{R}_{4}=\mathrm{H}$

$18: \mathrm{R}_{1}=\mathrm{R}_{2}=\mathrm{R}_{3}=\mathrm{R}_{4}=\mathrm{OCH}_{3}$

Figure 3: Chemical structures of the acids and flavonoids identified from ethyl acetate and aqueous extracts of V. lippii.

$70.36 \mathrm{~min})$ were identified as 1,3 -di-O-caffeoylquinic; 3,4 -di$O$-caffeoylquinic; and 4,5-di-O-caffeoylquinic acids, respectively $[35,36]$. It should be noted that 1,3 -di-O-caffeoylquinic acid was only detected in the aqueous fraction.

3.7.2. Phenolic Acid Derivatives. The MS spectra of compounds $2,3,5,6$, and 8 indicated specific fragments which prove the presence of free phenolic acids (Table 5). The UV spectra of peaks 5 and 8 showed the same absorption maximum at $332 \mathrm{~nm}$ typical of cinnamic acid derivatives [34]. Peak $5\left(t_{R} 21.22\right.$ min) was identified as caffeic acid by comparing with a reference compound and according to its deprotonated molecular ion $[\mathrm{M}-\mathrm{H}]^{-}$at $\mathrm{m} / \mathrm{z} 179$ and

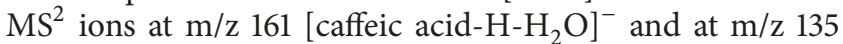
[caffeic acid- $\left.\mathrm{H}-\mathrm{CO}_{2}\right]^{-}[37,38]$. Ferulic acid (peak 8, $\mathrm{t}_{\mathrm{R}} 42.30$ min) was easy to identify by its MS ions at $\mathrm{m} / \mathrm{z} 191$ [M$\mathrm{H}]^{-}$and at $\mathrm{m} / \mathrm{z} 149$ [ferulic acid- $\left.\mathrm{H}-\mathrm{CO}_{2}\right]^{-}$[37]. Moreover, peaks $2\left(t_{R} 7.86 \mathrm{~min}\right), 3\left(t_{R} 11.21 \mathrm{~min}\right)$, and $6\left(t_{R} 23.77\right.$ min) were tentatively assigned as gallic, protocatechuic, and syringic acids, respectively, based on the UV spectra, $\mathrm{MS}^{2}$ fragmentation pattern and previous report [38]. Gallic and syringic acids were only detected in the aqueous fraction.

3.7.3. Flavonoids. In ethyl acetate and aqueous fractions, flavonoids were represented with kaempferol and quercetin derivatives that exhibited typical UV spectra with band II in the $252-257 \mathrm{~nm}$ range and band $\mathrm{I}$ in the $350-359 \mathrm{~nm}$ range [34].
The assignment of peak $15\left(\mathrm{t}_{\mathrm{R}} 80.84 \mathrm{~min}\right)$ as kaempferol was done via its pseudomolecular ion $[\mathrm{M}-\mathrm{H}]^{-}$at $\mathrm{m} / \mathrm{z} 285$ and $\mathrm{MS}^{2}$ ions at $\mathrm{m} / \mathrm{z} 269$ and 179 [37]. Compounds $9\left(\mathrm{t}_{\mathrm{R}}\right.$ $59.01 \mathrm{~min})$ and $12\left(\mathrm{t}_{\mathrm{R}} 67.22 \mathrm{~min}\right)$ produced characteristic $\mathrm{MS}^{2}$ ion at $\mathrm{m} / \mathrm{z} 301$ which corresponds to quercetin aglycone. Peak 9 revealed parent ion $[\mathrm{M}-\mathrm{H}]^{-}$at $\mathrm{m} / \mathrm{z} 609$ that releases $\mathrm{MS}^{2}$ fragments at $\mathrm{m} / \mathrm{z} 463$ [M-H-rhamnosyl] $]^{-}$and 301[M$\mathrm{H}$-rhamnosyl-glucosyl] ${ }^{-}$; therefore, it was identified as rutin [37]. While peak 12, having MS ions at $\mathrm{m} / \mathrm{z} 447[\mathrm{M}-\mathrm{H}]^{-}$ and $301[\mathrm{M}-\mathrm{H} \text {-rhamnosyl] }]^{-}$, was associated with quercetrin (quercetin-3-O-rhamnoside) [39].

Besides flavonols, five flavonones, possessing similar UV spectra, were discerned in the ethyl acetate and aqueous fractions. Apigenin (peak $16, t_{R} 89.16 \mathrm{~min}$ ) was easy to identify by its MS fragmentation ions at $\mathrm{m} / \mathrm{z} 269[\mathrm{M}-\mathrm{H}]^{-}$and at $\mathrm{m} / \mathrm{z}$ 179,151 , and 119 [35]. On the basis of literature data [36], peak $10\left(t_{R} 61.03 \mathrm{~min}\right)$ was tentatively assigned as luteolin7-O-glucoside (MS ions at m/z 447[M-H] ${ }^{-}$and 285 [luteolin$\left.\mathrm{H}]^{-}\right)$. Compounds $13\left(\mathrm{t}_{\mathrm{R}} 68.63 \mathrm{~min}\right), 17\left(\mathrm{t}_{\mathrm{R}} 99.73 \mathrm{~min}\right)$, and $18\left(t_{R} 102.51 \mathrm{~min}\right)$ were identified as apigenin-7- $O$-glucoside, cirsilineol, and acacetin, respectively, by comparison with standard compounds and with literature data [40].

3.8. Quantitative Phytochemical Analyses of Ethyl Acetate and Aqueous Fractions. The quantification analyses data of the identification constituents were achieved by HPLC. The amounts of the compounds, detected in the samples and expressed in $\mu \mathrm{g} / \mathrm{g}$ of dry material, were reported in Table 5. 
The results showed that quinic acid derivatives were the dominant components in ethyl acetate and aqueous fractions with percentages 95.93 and $96.96 \%$, respectively. On the other hand, phenolic acids and flavonoids were found for the two fractions in lower levels of contents which are less than $200 \mu \mathrm{g} / \mathrm{g}$ of dry material. Quinic, 3-O-caffeoylquinic, and 3,4di-O-caffeoylquinic acids were the most abundant acids in the two samples. The major quinic acid derivative in the ethyl acetate fraction was 3,4-di-O-caffeoylquinic acid (9849.46 $\mu \mathrm{g} / \mathrm{g}$ of dry material) while 3-O-caffeoylquinic acid was found the dominant compound in the aqueous fraction (11721.58 $\mu \mathrm{g} / \mathrm{g}$ of dry material). Several works reported that the 3,4-di$O$-caffeoylquinic acid exhibited antioxidant [41], antidiabetic [42], antibacterial [43], cytotoxic [42], and anti-HVS-1 effects [44]. Also, 3-O-caffeoylquinic acid was mentioned possessing antioxidant [45], antidiabetic [46], antimicrobial [47], and anti-Alzheimer activities [48]. Thus, the biological activities of $V$. lippii fractions could be related to the high amounts of quinic acid derivatives and specially 3 -O-caffeoylquinic and 3,4-di-O-caffeoylquinic acids.

\section{Conclusions}

This paper is the first report that highlights the antioxidant, antiacetylcholinesterase, antidiabetic, and antibacterial proprieties of $V$. lippii. Among all the extracts, ethyl acetate and aqueous fractions exhibited the greater biological activities and the highest levels in total phenolic and flavonoid contents. LC-ESI-MS/MS analyses of these two fractions led to the identification of eighteen compounds belonging to phenolic acids and flavonoids, where quinic, 3-O-caffeoylquinic and 3,4-di-O-caffeoylquinic acids were present in higher amounts. Therefore, the qualitative and quantitative analyses of major constituents in V. lippii samples could be helpful for understanding the relationship between the total phenolic and flavonoid contents and their biological activities. However, further studies are required to isolate new bioactive components in the ethyl acetate and aqueous fractions and to evaluate their in vivo biological capacities.

\section{Data Availability}

All data used to support the findings of this study are included within the article.

\section{Conflicts of Interest}

Authors declare that there are no conflicts of interest regarding the publication of this paper.

\section{Acknowledgments}

This research was supported by the Ministry of Higher Education and Scientific Research under grant agreement LR17ES08, Tunisia.

\section{References}

[1] M. M. Boukef, "Les plantes dans la médecine traditionnelle tunisienne, Agence de coopération culturelle et technique, Paris, 1986".

[2] N. Jdaidi and B. Hasnaoui, "Etude floristique et ethnobotanique des plantes médicinales au nord-ouest de la Tunisie: cas de la communauté d'Ouled Sedra," Journal of Advanced Research in Science and Technology, vol. 3, pp. 281-291, 2016.

[3] S. Felhi, N. Baccouch, H. Ben Salah et al., "Nutritional constituents, phytochemical profiles, in vitro antioxidant and antimicrobial properties, and gas chromatography-mass spectrometry analysis of various solvent extracts from grape seeds (Vitis vinifera L.)," Food Science and Biotechnology, vol. 25, no. 6, pp. 1537-1544, 2016.

[4] H. B. Miled, M. Saada, I. Jallali et al., "Variability of antioxidant and biological activities of Rhus Tripartitum related to phenolic compounds," Excli Journal, vol. 16, pp. 439-447, 2017.

[5] W. Greuter, "Proposals to conserve the names Leysera against Asteropterus, Volutaria against Amberboi, Rhaponticum with a conserved type, and Rhaponticoides against Bielzia (Compositae)," Taxon, vol. 57, no. 3, pp. 1001-1002, 2008.

[6] J. Kadereit and C. Jeffrey, "Families and Genera of Vascular Plants,” K. Kubitzki, Ed., vol. 8, p. 141, Springer, Berlin, Heidelberg, Germany, 2007.

[7] S. B. Khan, K. Akhtar, A. Malik, E. S. Jang, and H. Han, "Pharmaceutical prospecting of natural products from the genus Amberboa," Journal of Medicinal Plants Research, vol. 4, no. 11, pp. 1039-1052, 2010.

[8] A. M. Marzouk, "Investigating Volutaria abyssinica as a potential source for cytotoxic sesquiterpenoids," Journal of American Science, vol. 11, pp. 73-81, 2015.

[9] N. Mezache, D. Bendjeddou, D. Satta, R. Mekkiou, S. Benayache, and F. Benayache, "Secondary metabolites from Centaurea lippii," Chemistry of Natural Compounds, vol. 46, no. 5, pp. 801-802, 2010.

[10] J. B. Bermejo, C. Betancor, J. L. F. Breton, and A. G. Gonzalez, "Sesquiterpene lactones of Amberboa lippii," Anales de Química, vol. 65, pp. 285-295, 1969.

[11] J. L. F. Breton, B. M. Garcia, and A. G. Gonzalez, "Sesquiterpene lactones of Amberboa lippii. Structure of grosshemine," Anales de Química, vol. 64, pp. 1015-1016, 1968.

[12] H. Y. Chen, Y. C. Lin, and C. L. Hsieh, "Evaluation of antioxidant activity of aqueous extract of some selected nutraceutical herbs," Food Chemistry, vol. 104, no. 4, pp. 1418-1424, 2007.

[13] A. Djeridane, M. Yousfi, B. Nadjemi, D. Boutassouna, P. Stocker, and N. Vidal, "Antioxidant activity of some Algerian medicinal plants extracts containing phenolic compounds," Food Chemistry, vol. 97, no. 4, pp. 654-660, 2006.

[14] F. Les, J. M. Prieto, J. M. Arbonés-Mainar, M. S. Valero, and V. López, "Bioactive properties of commercialised pomegranate (Punica granatum) juice: antioxidant, antiproliferative and enzyme inhibiting activities," Food \& Function, vol. 6, no. 6, pp. 2049-2057, 2015.

[15] P. Prieto, M. Pineda, and M. Aguilar, "Spectrophotometric quantitation of antioxidant capacity through the formation of a phosphomolybdenum complex: specific application to the determination of vitamin E," Analytical Biochemistry, vol. 269, no. 2, pp. 337-341, 1999.

[16] A. Yildirim, A. Mavi, and A. A. Kara, "Determination of antioxidant and antimicrobial activities of Rumex crispus L. 
extracts," Journal of Agricultural and Food Chemistry, vol. 49, no. 8, pp. 4083-4089, 2001.

[17] G. L. Ellman, K. D. Courtney, V. Andres Jr., and R. M. Featherstone, "A new and rapid colorimetric determination of acetylcholinesterase activity," Biochemical Pharmacology, vol. 7, no. 2, pp. 88-95, 1961.

[18] F.-J. Gella, G. Gubern, R. Vidal, and F. Canalias, "Determination of total and pancreatic $\alpha$-amylase in human serum with 2chloro-4-nitrophenyl- $\alpha$-D-maltotriosid as substrate," Clinica Chimica Acta, vol. 259, no. 1-2, pp. 147-160, 1997.

[19] V. A. Berghe and A. J. Vlietinck, "Screening methods for antibacterial and antiviral agents from higher plants," Methods in Plant Biochemistry, vol. 6, pp. 47-68, 1991.

[20] M. Karker, H. Falleh, K. Msaada et al., "Antioxidant, antiinflammatory and anticancer activities of the medicinal halophyte Reaumuria vermiculata," Excli Journal, vol. 15, pp. 297307, 2016.

[21] C. Karamenderes, S. Konyalioglu, S. Khan, and I. A. Khan, "Total phenolic contents, free radical scavenging activities and inhibitory effects on the activation of NF-kappa B of eightCentaurea L. species," Phytotherapy Research, vol. 21, no. 5, pp. 488-491, 2007.

[22] M. Kchaou, H. B. Salah, R. Mhiri, and N. Allouche, "Antioxidant and anti-acetylcholinesterase activities of Zygophyllum album," Bangladesh Journal of Pharmacology, vol. 11, no. 1, pp. 54-62, 2016.

[23] K. Mnafgui, M. Kchaou, H. Ben Salah et al., "Essential oil of Zygophyllum album inhibits key-digestive enzymes related to diabetes and hypertension and attenuates symptoms of diarrhea in alloxan-induced diabetic rats," Pharmaceutical Biology, vol. 54, no. 8, pp. 1326-1333, 2016.

[24] Y. Chu, C. Chang, and H. Hsu, "Flavonoid content of several vegetables and their antioxidant activity," Journal of the Science of Food and Agriculture, vol. 80, no. 5, pp. 561-566.

[25] H. Ben Salah, M. Kchaou, R. Ben Abdallah Kolsi et al., "Chemical composition, characteristics profiles and bioactivities of Tunisian Phalaris canariensis seeds: a potential source of $\omega-6$ and $\omega-9$ fatty acids," Journal of Oleo Science, vol. 67, no. 7, pp. 801-812, 2018.

[26] N. Baccouch, H. Ben Salah, S. Belhaj et al., "Chemical characterization and biological activities of Simmondsia chinensis (Link) C. K. Schneid seeds oil," Cellular and Molecular Biology, vol. 64, no. 4 , p. 11, 2018.

[27] B. Halliwell, "Reactive oxygen species in living systems: Source, biochemistry, and role in human disease," American Journal of Medicine, vol. 91, no. 3 C, pp. S14-S22, 1991.

[28] K. Sowndhararajan and S. C. Kang, "Free radical scavenging activity from different extracts of leaves of Bauhinia vahlii Wight \& Arn.," Saudi Journal of Biological Sciences, vol. 20, no. 4, pp. 319-325, 2013.

[29] R. B. Kolsi, H. B. Salah, S. A. Saidi, N. Allouche, H. Belghith, and K. Belghith, "Evaluation of nutritional value, characteristics, functional properties of Cymodocea nodosa and its benefits on health diseases," Lipids in Health and Disease, vol. 16, no. 1, 2017.

[30] M. C. Carpinella, D. G. Andrione, G. Ruiz, and S. M. Palacios, "Screening for acetylcholinesterase inhibitory activity in plant extracts from Argentina," Phytotherapy Research, vol. 2, pp. 259263, 2010.

[31] A. Aktumsek, G. Zengin, G. O. Guler, Y. S. Cakmak, and A. Duran, "Antioxidant potentials and anticholinesterase activities of methanolic and aqueous extracts of three endemic Centaurea
L. species," Food and Chemical Toxicology, vol. 55, pp. 290-296, 2013.

[32] E. Giacobini, "Cholinesterase inhibitors: new roles and therapeutic alternatives," Pharmacological Research, vol. 50, no. 4, pp. 433-440, 2004.

[33] G. Zengin, M. Locatelli, S. Carradori, A. M. Mocan, and A. Aktumsek, "Total phenolics, flavonoids, condensed tannins content of eight centaurea species and their broad inhibitory activities against cholinesterase, tyrosinase, $\alpha$-amylase and $\alpha$-glucosidase," Notulae Botanicae Horti Agrobotanici ClujNapoca, vol. 44, no. 1, pp. 195-200, 2016.

[34] B. R. Kumar, "Application of HPLC and ESI-MS techniques in the analysis of phenolic acids and flavonoids from green leafy vegetables (GLVs)," Journal of Pharmaceutical Analysis, vol. 7, no. 6, pp. 349-364, 2017.

[35] S. C. Gouveia and P. C. Castilho, "Artemisia annua L.: essential oil and acetone extract composition and antioxidant capacity," Industrial Crops and Products, vol. 45, pp. 170-181, 2013.

[36] K. Schütz, D. Kammerer, R. Carle, and A. Schieber, "Identification and quantification of caffeoylquinic acids and flavonoids from artichoke (Cynara scolymus L.) heads, juice, and pomace by HPLC-DAD-ESI/MSn," Journal of Agricultural and Food Chemistry, vol. 52, no. 13, pp. 4090-4096, 2004.

[37] N. Miceli, A. Filocamo, S. Ragusa et al., "Chemical characterization and biological activities of phenolic-rich fraction from Cauline leaves of Isatis tinctoria L. (Brassicaceae) growing in Sicily, Italy," Chemistry \& Biodiversity, vol. 14, 2017.

[38] J. C. Zivkovic, J. C. M. Barreira, K. P. Šavikin et al., "Chemical profiling and assessment of antineurodegenerative and antioxidant properties of Veronica teucrium L. and Veronica jacquinii Baumg," Chemistry \& Biodiversity, vol. 14, 2017.

[39] X. H. Yao, D. Y. Zhang, Y. G. Zu et al., "Free radical scavenging capability, antioxidant activity and chemical constituents of Pyrola incarnata Fisch. Leaves," Industrial Crops and Products, vol. 49, pp. 247-255, 2013.

[40] L. Alexandru, L. Pizzale, L. Conte, A. Barge, and G. Cravotto, "Microwave-assisted extraction of edible Cicerbita alpina shoots and its LC-MS phenolic profile," Journal of the Science of Food and Agriculture, vol. 93, no. 11, pp. 2676-2682, 2013.

[41] I. Dini, G. C. Tenore, and A. Dini, "New Polyphenol Derivative in Ipomoea batatas Tubers and Its Antioxidant Activity," Journal of Agricultural and Food Chemistry, vol. 54, no. 23, pp. 87338737, 2006.

[42] K. L. Ooi, T. S. Muhammad, M. L. Tan, and S. F. Sulaiman, "Cytotoxic, apoptotic and anti- $\alpha$-glucosidase activities of 3,4di-O-caffeoyl quinic acid, an antioxidant isolated from the polyphenolic-rich extract of Elephantopus mollis Kunth., Journal of Ethnopharmacology, vol. 135, no. 3, pp. 685-695, 2011.

[43] H. F. Harrison, T. R. Mitchell, J. K. Peterson, W. P. Wechter, G. F. Majetich, and M. E. Snook, "Contents of caffeoylquinic acid compounds in the storage roots of sixteen sweetpotato genotypes and their potential biological activity," Journal of the American Society for Horticultural Science, vol. 133, no. 4, pp. 492-500, 2008.

[44] C. O. Rezende, C. Rigotto, W. Caneschi et al., "Anti-HSV-1 and antioxidant activities of dicaffeoyl and digalloyl esters of quinic acid," Biomedicine \& Preventive Nutrition, vol. 4, no. 1, pp. 3538, 2014.

[45] H. Morishita and M. Ohnishi, "Absorption, metabolism and biological activities of chlorogenic acids and related compounds," Studies in Natural Products Chemistry, vol. 25, pp. 919953, 2001. 
[46] Shengx Meng I, Jianme Cao I, Qin Feng, Jinghua Peng, and Yiyang $\mathrm{Hu}$, "Roles of chlorogenic acid on regulating glucose and lipids metabolism: a review," Evidence-Based Complementary and Alternative Medicine, vol. 2013, Article ID 801457, 11 pages, 2013.

[47] Z. Lou, H. Wang, S. Zhu, C. Ma, and Z. Wang, "Antibacterial activity and mechanism of action of chlorogenic acid," Journal of Food Science, vol. 76, no. 6, pp. M398-M403, 2011.

[48] I. Orhan, M. Kartal, F. Tosun, and B. Şener, "Screening of various phenolic acids and flavonoid derivatives for their anticholinesterase potential," Zeitschrift für Naturforschung C, vol. 62, no. 11-12, pp. 829-832, 2007. 


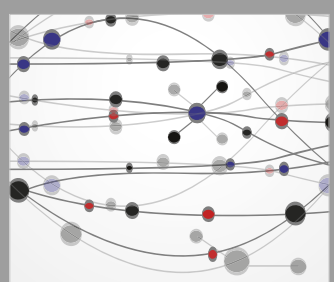

The Scientific World Journal
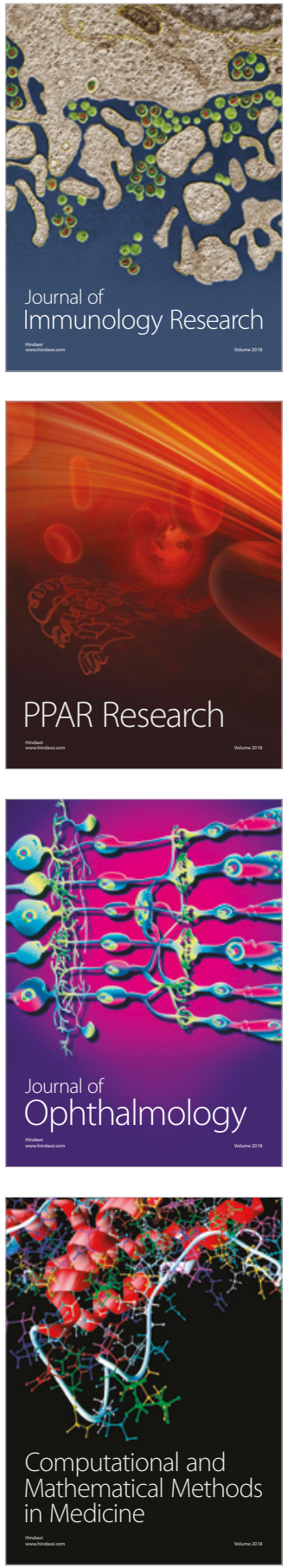

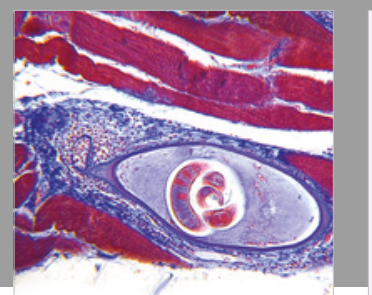

Gastroenterology Research and Practice

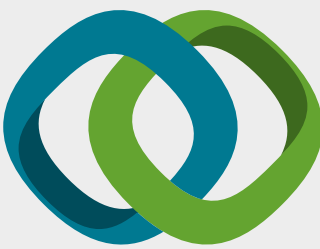

\section{Hindawi}

Submit your manuscripts at

www.hindawi.com
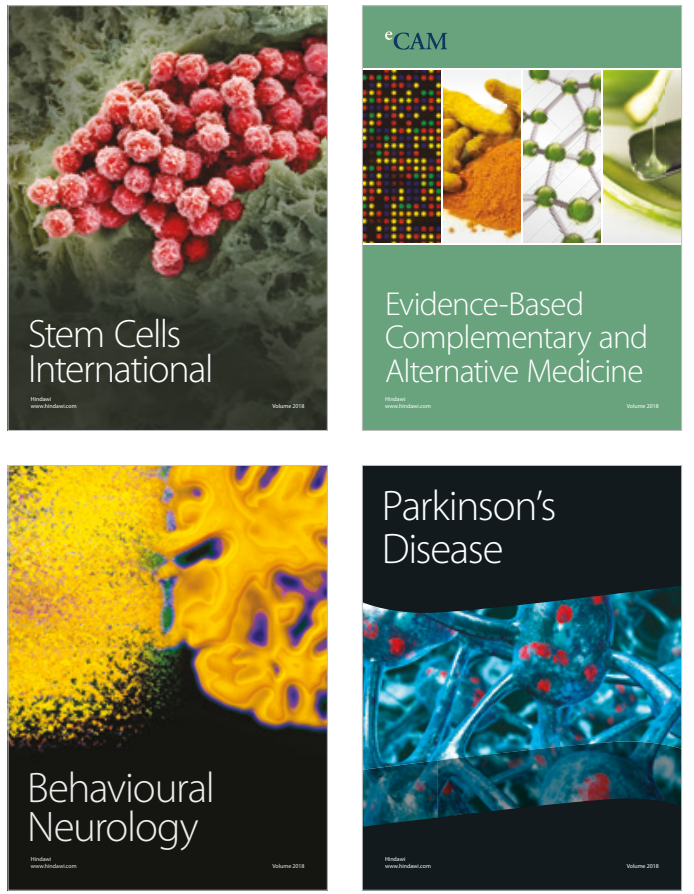

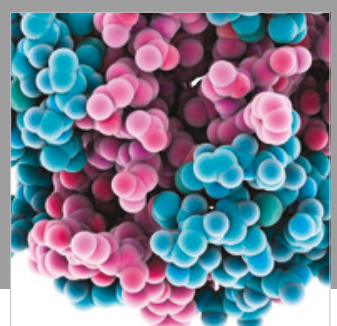

ournal of

Diabetes Research

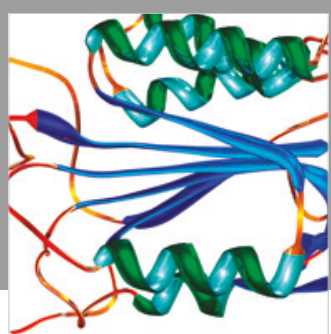

Disease Markers
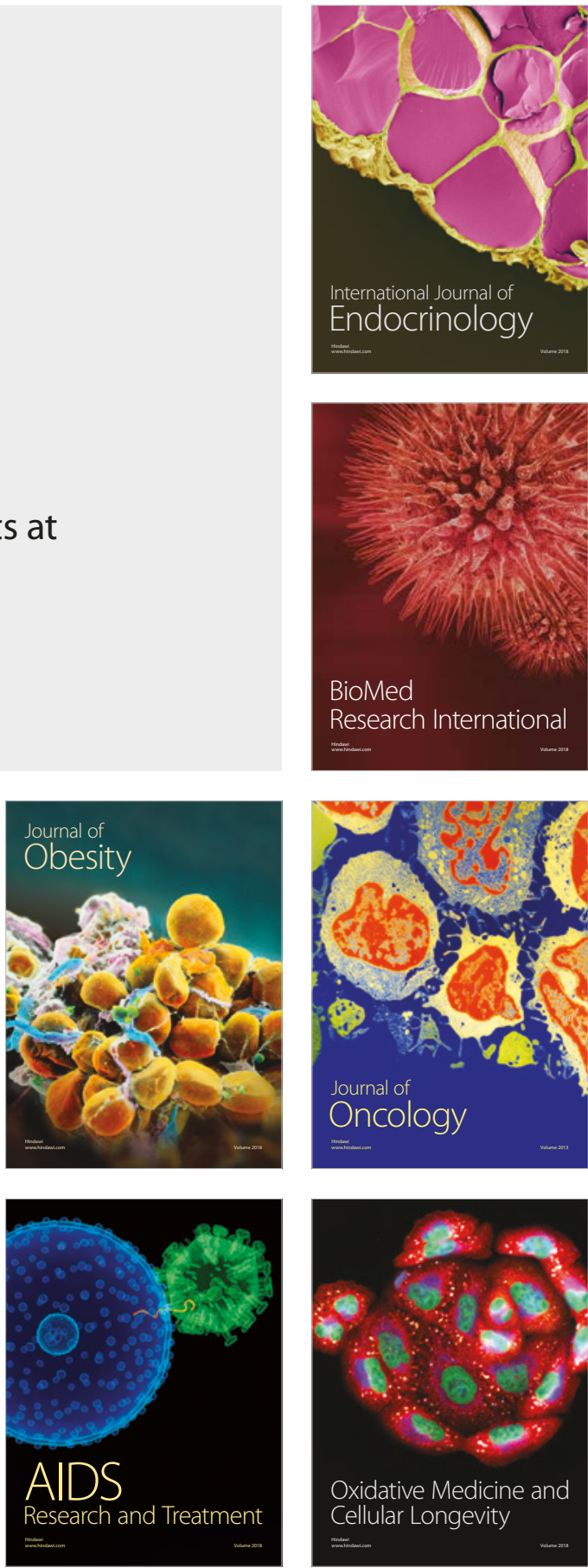